\title{
Strategic Autonomy of the European Union in Security and Defence
}

\begin{abstract}
The paper presents theoretical considerations regarding the understanding of strategic autonomy in the field of security and defence. It starts with the theoretical understanding of the term "autonomy" and dilemmas concerning autonomy in the EU. Then it identifies and describes the key initiatives in the field of security and defence conditioning the EU's achievement of strategic autonomy in this area and the main problems of their implementation. The presented conclusions are based on the qualitative analysis of the source material, mainly, the EU normative documents. They lead to the following observations. First, there is no clear definition and interpretation of "strategic autonomy" in the EU normative documents. This can lead to confusion and over-interpretation by individual Member States which may understand strategic autonomy differently, especially in the area of security and defence. Secondly, the majority of the Member States recognise security and defence as an area enabling the achievement of strategic autonomy. However, there are differences between countries in terms of understanding strategic autonomy. Two approaches are visible amongst the EU members: full sovereignty and flexible autonomy in the field of security and defence. Thirdly, the security and defence initiatives adopted by the EU over the past few years can provide the basis for achieving strategic autonomy in this area.
\end{abstract}

\section{Introduction}

The European security environment has deteriorated significantly over the past few years. Terrorism, illegal migration, failed states, and civil wars in the South have increased the threats to the security of the Europeans. Tensions with Russia regarding the status of Crimea and the territory of eastern Ukraine also pose serious challenges to peace and stability in Europe. In addition to this, uncertainty about the future commitments of the United States to European security having emerged during the presidency of Donald Trump as well as regional competition between Asian and Middle Eastern powers point to a turbulent environment around Europe. In connection with these events, the issue of security and defence in the European Union (EU) has come to the fore.

\footnotetext{
"Col., dr hab. Tadeusz Zieliński is an Associate Professor at War Studies University, Warsaw, Poland. Address for correspondence: al. gen. A. Chruściela "Montera" 103, 00-910 Warszawa, Poland; tel. +48-261-813-431; e-mail: t-zielinski@akademia.mil.pl
} 
Calls for closer EU defence cooperation, the establishment of "European Strategic Autonomy" or the creation of a genuine "European Army" - these are just some of the initiatives to give new impetus to the Common Security and Defence Policy (CSDP). What is more, these are not just empty words as they are followed by specific actions and initiatives. In the summer of 2016, the Global Strategy for the European Union's Foreign and Security Policy (EUGS) was presented, outlining the EU's foreign and security policy strategy - this was the first document of this kind in thirteen years. In July 2016, a new EU-NATO Joint Declaration was announced with the intention of deepening cooperation in many common areas related to security and defence. As a part of the first preliminary step to implement the EUGS, the Council adopted conclusions in November 2016 on its implementation in the field of security and defence, which the European Council approved at the December summit.

As a result of these decisions, the Permanent Structured Cooperation (PESCO) was launched on the basis of the Lisbon Treaty in the scope of conducting annual reviews and strengthening of the EU Battle Groups. At the same time, the Commission presented the European Defence Action Plan to accelerate financing of the European defence goals, as a result of which, in June 2017, the European Defence Fund was launched. In addition to this, in June 2017, High Representative Federica Mogherini, presented the future of the European defence as a part of the White Paper on the Future of Europe.

The concept of strategic autonomy was introduced by the High Representative of the Union for Foreign Affairs and Security Policy in June 2016, when she presented the EUGS to the European Council. This paper, including the EU's external action guidelines, aims to reach an 'appropriate level' of strategic autonomy in the field of defence and security. The EUGS remains quite vague, if not ambiguous, on the content and significance of this concept. The European strategic autonomy lacks a common definition and that can be the main obstacle for realization of the concept. Moreover, France and Germany are becoming the main players in the EU after the Brexit, but they have different views on defence and security matters. Smaller Member States also view the European strategic autonomy differently. European politicians began to duplicate the term strategic autonomy in debates on various spheres of the EU's functioning pointing out that the EU should strive to achieve strategic autonomy. However, there is no precise and clear definition of the meaning of strategic autonomy. One of the areas indicated by the representatives of the European Commission as a field where the EU should strive to achieve strategic autonomy is security and defence. However, the defence and security field is 
traditionally and primarily seen as a Member State's prerogative, so there may be different visions of achieving strategic autonomy amongst Members States. On the other hand, recently-introduced instruments can facilitate a much-needed compromise and eventual convergence in the CSDP field.

Ambitious plans for the Member States' cooperation under PESCO and EU-NATO cooperation as well as additional tools to ensure real development of the EU capabilities, such as the Capability Development Plan (CDP) and the Coordinated Annual Review on Defence (CARD), require raising the key questions related to the future of the EU in the field of security and defence in relation to strategic autonomy. First of all, how is strategic autonomy in the field of security and defence understood and is this reflected in the EU documents? Secondly, what actions taken by the EU in the field of security and defence offer the opportunity to achieve strategic autonomy? The paper tries to answer these questions.

The starting point for considering the EU's strategic autonomy in the field of security and defence was the qualitative analysis of available literature. The first group of pieces of literature included those related to the term of "autonomy". The second group encompassed normative documents related to the area of security and defence in the EU. The third one covered articles and studies of research institutes and think-tanks dealing with the EU issues, including the ones in the context of strategic autonomy in the field of security and defence.

The first chapter presents theory related to the concept of strategic autonomy in reference to different fields. However, it also proposes a clear definition in relation to the field of security and defence. The second chapter deals with dilemmas concerning strategic autonomy of the EU in terms of security and defence. It includes how strategic autonomy is perceived by the main actors of the EU. The third chapter presents the main initiatives strengthening the EU in achieving strategic autonomy in the field of security and defence.

\section{The concept of autonomy - theory}

The classic model proposed by Ruth Lapidoth includes four categories of the definition of "autonomy." The first one interprets autonomy as the right to act freely to a certain extent. The second category is related to the recognition of autonomy as a synonym of independence - to a greater or lesser extent. The third category includes definitions equating autonomy with decentralization. The fourth category contains definitions emphasizing that the autono- 
mous community has exclusive legislative, administrative and judicial rights in specific matters. ${ }^{1}$

The term "autonomy" is derived from the Greek word autónomos, meaning, as much as self-governing, independent. The etymology of the term comes from two words: autós, meaning, self-reliant, and nomós, meaning, custom, law, and principle. Initially, autonomy indicated the possibility of deciding on specific matters independently. Today it is combined with elements such as "independence, independence of phenomena, entities, often recognized in relation to other phenomena, entities and indicating their separateness or their independent function in society." As Heinrich Oberreuter points out, autonomy is a chance for self-determination under applicable legal provisions. ${ }^{2}$ In turn, Henry J. Steiner defines autonomous regimes as governmental systems or subsystems administered or managed by ethnic minorities or their members ${ }^{3}$, while Jan-Erik Lane and Svante Ersson indicate that autonomy may apply in determining both constituent parts of federal states and regions in a unitary state. ${ }^{4}$

Despite the wide range of comparative material and the growing number of studies on autonomy, there is still a lack of a single universally accepted definition and the concept itself remains vague. Gnanapala Welhengama uses a pictorial example and compares autonomy to a black cat in a dark room: although it cannot be seen, it can be concluded from its movements that it is there. ${ }^{5}$ The same applies to autonomy: the concept appears in international documents (such as the European Global Strategy), however, a precise definition and a precise specification of its implications does not seem possible. States are reluctant to use this term for fear that the use itself could be interpreted as an indirect recognition of the right to autonomy.

There is also no agreement on typology of autonomy and new research approaches (including Tkacik, Iwanek) are still competing with the "classical" approaches (including Lapidoth and Hannum). ${ }^{6}$ This is due to the fact that autonomy is the systemic solution that developed to a much greater extent ba-

\footnotetext{
${ }^{1}$ Lapidoth, R. (1997), Autonomy. Flexible Solutions to Ethnic Conflicts, Washington: United States Institute of Peace Press, p. 33.

${ }^{2}$ Oberreuter, H. (1995), “Autonomie”, In Staatslexikon, Vol. 1, Freiburg, Basel, Vienna: Herder, p. 491.

${ }^{3}$ Steiner, H.J. (1991), "Ideas and Counter-Ideas in the Struggle over Autonomy Regimes for Minorities", Notre Dame Law Review, 5 (66), p. 1561.

${ }^{4}$ Lane, J.-E., Ersson, S. (1994), Politics and Society in Western Europe. London: Sage Publications, p. 219.

${ }^{5}$ Welhengama, G. (1999), "The Legitimacy of Minorities. Claim for Autonomy through the Right to SelfDetermination", Nordic Journal of International Law, 4 (68), p. 425.

${ }^{6}$ Hannum, H., Lillich R.B. (1980), “The Concept of Autonomy in International Law”, American Journal of International Law, 4 (74), pp. 858-889.
} 
sed on practice and legal solutions than on theoretical models. ${ }^{7}$ There are many typologies of autonomy in the literature, sometimes even contradictory ones. Researchers use different criteria: because of the beneficiaries of the solution, because of the purpose of autonomy, or because of the relationship of the autonomous unit and the state of which it is a part of. Tkacik distinguishes five degrees of autonomy: from personal through cultural, functional, and administrative to legislative ones. Each level is stronger than the previous one. The researcher separates personal autonomy from the cultural one. He treats the first one as a guarantee of respecting the fundamental rights (mainly civil rights) of the individual not necessarily as a member of a specific group. Cultural autonomy, in turn, is a deliberate extension of applicable laws to a specific language or cultural group. Cultural autonomy, therefore, concerns the community, and personal autonomy of members of the community perceived as individuals. ${ }^{8}$ Benedikter does not agree with this approach, indicating that autonomous solutions should be group oriented, as the subject is to be the community. ${ }^{9}$

Tkacik defines functional autonomy as a process of decentralization of control over one clearly limited sphere of public activity, for example, language policy in a single school circuit. In turn, administrative autonomy implies a whole set of such functional autonomies (regarding, e.g., schools, courts, religion, public services). ${ }^{10}$ In practice, this means that numerous powers have been granted to the autonomous community. Permissions may or may not be associated with any overriding purpose. Corsica would be a classic example of administrative autonomy. Some authors, however, reject such a division, at best treating functional autonomy as a subcategory of cultural or administrative autonomy, and they often refer to the Finnish regulations regarding the Swedish minority (excluding the Åland Islands) as a special implementation of language regulations rather than a separate form of autonomy. ${ }^{11}$ Tkacik himself locates the situation of the Swedish-speaking population in Finland in a specific grey area of the typology he is building. ${ }^{12}$

\footnotetext{
${ }^{7}$ Iwanek, J. (2014), "Pojęcie autonomii terytorialnej we współczesnej europejskiej przestrzeni demokratycznej", [The notion of territorial autonomy in contemporary European democratic space], In Domagała, M., Iwanek, J. (eds.), Autonomia terytorialna w perspektywie europejskiej. Tom I: Teoria - historia [Territorial autonomy in a European perspective. Volume I: Theory - history], Toruń: Wydawnictwo Adam Marszałek, p. 5.

${ }^{8}$ Tkacik, M. (2008), "Characteristic of Forms of Autonomy”, International Journal on Minority \& Group Rights, 2/3(15), p. 371.

${ }^{9}$ Benedikter, T. (2009), The World's Modern Autonomy Systems. Concepts and Experiences of Regional Territorial Autonomy, Bolzano: Eurac, p. 40.

${ }^{10}$ Tkacik, M. (2008), op. cit., p. 380.

${ }^{11}$ Benedikter, T. (2009), op. cit.

${ }^{12}$ Tkacik, M. (2008), op. cit.
} 
At the top of the Tkacik (2008) typological model there is legislative autonomy, which is distinguished from the administrative autonomy by the scope and extent of the delegated powers. Functional autonomy also involves delegating powers, but - unlike legislative autonomy - it does not grant any legislative powers, i.e., it does not require establishment of the bodies issuing the laws generally applicable in a given community. An additional differentiating element is the geographical separateness of most legislative autonomies. However, the author himself admits that there is a grey zone that cannot be classified between individual types of autonomy (especially between administrative and legislative autonomy). ${ }^{13}$

With regard to the EU and its aspirations to obtain strategic autonomy not specified in the normative documents (see EUGS), the main ambitions are focused on functional autonomy covering primarily the sphere of security and defence and the foreign policy sphere directly related to it. In this context strategic autonomy can be defined as a policy aimed at gaining or preserving a large degree of independence in the field of security and defence identified as a strategic one. The objective is to maximise the autonomy of decision-making of the EU in the area of security and defence within the framework of an international system. Alexander Wendt defined autonomy as "the ability of a state-society complex to exercise control over its allocation of resources and choices of government" not only to "survive" but also to retain its "liberty". 14

Strategic autonomy can be identified as the EU's ability to guarantee its security - in land, air, sea, space and cyberspace - to project power in and outside of its boundaries, and for its political action to be free and independent from any external authority. Furthermore, strategic autonomy could be narrowly defined as defence technological and industrial autonomy or it could be outlined in terms of total autonomy, including operational independence and territorial defence. However, taking to understand strategic autonomy merely from military terms is not an appropriate way, although military capacity goes a long way into the political realm. The term autonomy is relational by definition: the EU needs to be autonomous vis-à-vis other great powers. Broadly speaking, this concept may be commonly understood as the capacity to act and cooperate with partners whenever possible while being able to operate independently whenever necessary. Strategic autonomy is not about self-sufficiency but about the means and tools to diminish external dependencies in areas considered strategic and where dependencies could deal with autonomy,

\footnotetext{
${ }^{13}$ Ibidem, p. 401.

${ }^{14}$ Wendt, A. (1999), Social Theory of International Politics, Cambridge: Cambridge University Press, p. 98.
} 
whilst continuing to cooperate with partners in a multilateral setting. European strategic autonomy should be a concept not directed against anyone. It is not questioning transatlantic cooperation, not questioning support to NATO as the foundation for collective defence, it only shows the need to become a more relevant partner for the EU allies across the Atlantic as well as in other fora as the global security provider, which is what the EU has the ambition to do. Defence cooperation is the key element of strategic autonomy. There will be no strategic autonomy in Europe without defence cooperation.

The aforementioned considerations lead to a conclusion that strategic autonomy of the EU can be defined as a set of discourses and strategies aimed at safeguarding the freedom of actions taken in using defence capabilities in order to attain security of the Member States of the EU. So, the main goal is to create or to keep a sufficient strategic space in order to maintain autonomous rooms (in terms of security and defence) to manoeuvre the decisions made in Europe.

\section{Dilemmas concerning strategic autonomy of the EU in security and defence}

The term "strategic autonomy", despite its fairly frequent use in various contexts in relation to EU security and defence, is not clearly understood and interpreted. One of the few definitions was proposed by Arunoday Bajpai. He states that strategic autonomy refers to "a foreign policy posture, whereby a nation maintains independent outlook and orientation in foreign affairs with respect to the issues defining its core interests." ${ }^{15}$ Referring to this definition, strategic autonomy should be one of the European objectives going beyond the interests of individual EU Member States, so that they are able to ensure security. The EU's strategic autonomy can be implemented at many levels and in many areas. When developing the cited definition, one should consider understanding the key elements of the definition: "independent" and "core interests". The former suggests that the EU can act alone, if necessary. On the other hand, the second one, if understood in the simplest terms, means that it can be the sum of the national interests of the Member States. The problem is that national interests are multi-faceted and diverse. There are visible differences in

\footnotetext{
${ }^{15}$ Bajpai, A. (2020), "What is meant by Strategic Autonomy with respect to India's foreign Policy?" Quora, Available at: https://www.quora.com/What-is-meant-by-Strategic-Autonomy-with-respect-to-Indiasforeign-Policy, (Accessed: 27 July 2020).
} 
the perception of threats by Eastern European and Southern European countries in the modern European security environment. The lack of consensus in determining the "core interests" means that strategic autonomy cannot be defined through the interests of the EU Member States. This would lead to their lowest common understanding, and the EU's ambitions are decidedly higher. The answer to the definition of the "core interests" may be the content of the EU Global Strategy, which defines "shared interests": a) promoting the security of the citizens of the Member States in the internal and external dimension; b) prosperity requiring an open and reliable international economic system and constant access to global social goods, taking into account the European economy and the need for uninterrupted supply of natural resources; c) increasing the resilience of EU democracy and respecting and promoting its norms and values; and d) promoting a global rule-based order with the key principle of multilateralism. ${ }^{16}$

The EU may define its strategic autonomy by the need for capability and cooperation internationally and with regional partners - while being able to act independently where possible - where and when necessary. ${ }^{17}$ Thus, this applies to the ability of European countries to set their own priorities and make independent decisions on foreign policy, security and defence policy, and to have funds enabling implementation of defined priorities and decisions made individually or with partners. Most proponents of the concept of the EU's strategic autonomy argue that Europe should take full responsibility for security in Europe as a remedy for the US's uncertain stance on these issues. At the same time, they emphasise that this does not mean rejecting alliances and cooperation with partners outside the EU, on the contrary, greater involvement by the EU will strengthen transatlantic relations and Europe's security in the further environment. In turn, critics of the EU's strategic autonomy question the EU's ability to achieve strategic autonomy in the field of security and defence and warn against deterioration of relations with the United States (especially in the defence industry). They are also concerned about the French approach to security and defence, which would completely eliminate the involvement of a partner from across the Atlantic in defence and security matters. ${ }^{18}$

\footnotetext{
${ }^{16}$ EEAS (2016), "Shared Vision, Common Action: A Stronger Europe. A Global Strategy for the European Union's Foreign And Security Policy”, Available at: https://eeas.europa.eu/archives/docs/top_stories/pdf/ eugs_review_web.pdf, (Accessed: 30 July 2020).

${ }^{17}$ Camporini, V., Hartley, K., Maulny, J.P., Zandee, D. (2017), "European Preference, Strategic Autonomy and European Defence Fund", Armament Industry European Research Group, Available at: https://www. clingendael.org/sites/default/files/2017-11/Ares-22-Report-Nov-2017.pdf, (Accessed: 30 July 2020). ${ }^{18}$ Drent, M. (2018), "European strategic autonomy: Going it alone?", Clingendael - the Netherlands Institute of International Relations, Available at: https:/www.clingendael.org/sites/default/files/2018-08/PB_European_Strategic_Autonomy.pdf, (Accessed: 30 July 2020).
} 
The lack of a comprehensive and unambiguously interpreted definition means that the understanding of the EU's strategic autonomy varies among the Member States and within the individual EU policies. ${ }^{19}$ In the field of security and defence, it refers to activity in four dimensions: political, institutional, capability, and industrial..$^{20}$ The first dimension, i.e., political autonomy, concerns the EU leadership, in terms of who can guide the development of strategic autonomy and what the level of the EU ambition is in this regard. Institutional autonomy refers to the flexibility of managing the structures required to implement strategic autonomy. In turn, capabilities should describe the actual availability of military, civil, financial, operational and other resources to reliably implement priorities and decisions in the area of strategic autonomy. The dimension of industrial autonomy refers to the technological base that should provide defence capabilities ensuring the implementation of the EU's strategic autonomy. The model of strategic autonomy based on four pillars indicates that its implementation is gradual and developmental. The EU can work towards a gradual increase in autonomy and is likely to reach a greater degree in some dimensions than in others. ${ }^{21}$

The aforementioned dilemmas are visible in discussions of the EU Member States as well. The EU Member States can be divided into three groups with regard to achieving the EU's strategic autonomy in the field of security and defence. The first one is strongly in favour of its implementation and is primarily made up of France, Germany, Italy, and Spain. The second group of countries is neutral (e.g., the Baltic States, Hungary). On the other hand, the third group of states clearly contests the importance of strategic autonomy as a threat to the role of NATO and transatlantic relations (e.g., Poland, the Netherlands, Sweden, Denmark). France is the greatest supporter of strategic autonomy in the EU. This is determined by the fact that the concept of strategic autonomy is one of the main rules of its national defence policy, considering it as a condition of its sovereignty and ability to play a full role in international relations. So, France promotes the extension of its concept of strategic autonomy to the European

\footnotetext{
${ }^{19}$ Howorth, J. (2019), "Strategic Autonomy. Why It's Not About Europe Going it Alone”, Wilfried Martens Centre for European Studies, Available at: https://www.martenscentre.eu/sites/default/files/publicationfiles/strategic-autonomy-europe.pdf, (Accessed: 30 July 2020).

${ }^{20}$ Varga, G. (2017), “Towards European Strategic Autonomy? Evaluating the New CSDP Initiatives”, Institute for Foreign Affairs and Trade, Available at: https://kki.hu/assets/upload/07_KKI-Studies_CSDP_VargaG_20171003.pdf, (Accessed: 30 July 2020).

${ }^{21}$ Järvenpää, P., Major, C., Sakkov, S. (2019), "European Strategic Autonomy. Operationalising a Buzzword”, International Centre for Defence and Security, Available at: https://icds.ee/wp-content/uploads/2019/10/ ICDS_Report_European_Strategic_Autonomy_J\%C3\%A4rvenp\%C3\%A4\%C3\%A4_Major_Sakkov_October_2019.pdf, (Accessed: 30 July 2020).
} 
level. The French impact is apparent in the development of the concept in the current European strategic thinking. It considers that strategic autonomy rests on a political foundation comprised of two pillars: a high degree of industrial and technological autonomy on the one hand, and the means and resources to ensure operational autonomy on the other hand. There is a relative merging to present strategic autonomy as the mixture of political autonomy, operational autonomy and industrial autonomy ${ }^{22}$. In Germany - a country that can be often seen as the balancing force between transatlantic and European extremes - there is a quite interesting understanding of the European strategic autonomy, which is affected by the Germans' commitment to European integration and their complicated history of using military force. In many respects the Germans see the European strategic autonomy as dependent on the EU's unity and strong political structure, which can be seen as a precondition for the development and submission of any capability. It is therefore a part of a broader European integration project. According to Germany, despite a certain focus on Europe, this course in developing CSDP does not oppose maintaining a strong transatlantic partnership. Positive developments in the EU's security and defence policy are seen, rather, as advantageous for both parties ${ }^{23}$.

The voices from neutral countries, such as the Baltic States, are relatively free to formulate their vision for the European strategic autonomy in ways that fit their defence policy interests best. They would be interested in getting greater cross-border defence industrial cooperation, integration, consolidation and investments which would make them an integral part of the European defence industrial base. In this regard, the European mechanisms, which encourage engagement of as many Member States and ensure equal playing ground, especially for the SMEs, which dominate the industrial supply base of the Baltic States, are of particular importance. On the other hand, their strong transatlanticist strategic orientation makes them cautious with regard to initiatives, which may erode the transatlantic cooperation and relations with the U.S. defence industry. Their focus on increasing export potential and competitiveness as well as their concerns about the security of supply and access to cutting-edge sensitive technologies in such domains as cyber security seem to

\footnotetext{
${ }^{22}$ Brustlein, C. (2018), "European Strategic Autonomy: Balancing Ambition and Responsibility”, Ifri, Available at: https://www.ifri.org/sites/default/files/atoms/files/brustlein_european_strategic_autonomy_2018. pdf, (Accessed: 20 October 2020).

${ }^{23}$ Arteaga, F., Jermalavicius, T., Marrone, A., Maulny, J-P., Terlikowski, M. (2016), "Appropriate Level Of European Strategic Autonomy", Report No. 8, Armament Industry European Research Group, Available at: https://icds.ee/wp-content/uploads/2016/ARES-Group-Report-Strategic-autonomy-November-2016.pdf, (Accessed: 20 October 2020).
} 
make the Baltic States rather natural champions of the middle level European strategic autonomy, where such considerations are held in mutual balance ${ }^{24}$.

An example of countries contesting the strategic autonomy of the EU is Poland. It treats the concept as a question for the future adaptation of NATO to the growing Russian threat, rather than the fate of the EU as a strategic actor. Therefore, Poland has supported and is likely to support most of the European initiatives, aimed at broadening the pool of capabilities available for the common defence under NATO commitments. Consequently, the European strategic autonomy is seen in Poland as falling within the context of the transatlantic cooperation. To assure a continued and effective U.S. engagement in European security, NATO Allies from Europe need to deliver more in terms of defence spending and acquired capabilities. The ability of Europe to take a bigger share of the burden to defend itself and also to stabilize its neighbourhood is considered as one of the key factors, which will decide upon the future of the transatlantic cooperation and security of Europe as a whole $e^{25}$.

Strategic autonomy has become a key expression in recent debates on CSDP and EU documents. However, its specific meaning has never been officially defined, hence differences in interpretation between the Member States are evident. The most widely shared definition refers to the EU's ability to conduct demanding military operations in Europe's nearest surroundings. Two major obstacles characterise the EU's inability to achieve strategic autonomy: political divisions and military weakness. The main obstacles to the deepening of cooperation in the field of security and defence between Member States relate primarily to concerns about sovereignty and mutual trust, technical, bureaucratic and financial obstacles as well as issues related to the defence industry.

European countries should strive for strategic autonomy in the field of security and defence, including clearly defining terminology and concepts in this area. Lack of interpretative clarity may cause misunderstandings in matters relating to security and defence. The EU's ambitions in the context of strategic autonomy should also be clearly defined while unrealistic and controversial ideas that depart from the heart of the debate in this regard should be avoided. One example is the idea of a European army, which raises much controversy among Member States. The EU should make every effort to explain the idea of strategic autonomy to key partners, in particular the United States. ${ }^{26}$ This is a proposal aimed at strengthening security and defence in the transatlan-

\footnotetext{
${ }^{24}$ Ibidem.

${ }^{25}$ Ibidem.

${ }^{26}$ Thompson, J. (2019), “European Strategic Autonomy and the US”, Center for Security Studies (CSS) at ETH Zurich, Available at: https://doi.org/10.3929/ethz-b-000362178, (Accessed: 3 August 2020).
} 
tic dimension presenting with wider possibilities. Furthermore, this does not cause problems within NATO and closer EU-NATO cooperation is beneficial for everyone in terms of security and defence. ${ }^{27}$ Working out a compromise in the field of development of defence capabilities and future use thereof is a challenge which, in relation to the strategic autonomy of the EU, should reflect the following areas: a) a common level of ambition and perception of threats; b) harmonization of the development of defence capabilities; c) joint security and defence projects; d) cooperation with the key partners.

\section{Factors influencing the strategic autonomy of the EU in security and defence}

\subsection{A common level of ambition and perception of threats}

In terms of strategic autonomy, the starting point for discussion should be a definition of the vital interests of the EU as a necessary minimum ensuring the preservation of European values. Thus, it is important to determine the level of ambition and identify threats. It is hardly possible to define a common perception of threats to the EU security. It is the sum of the fears related to threats identified by individual Member States. ${ }^{28} \mathrm{~A}$ division into East and South Europe is visible in this context, where in the first case a narrative related to threats from Russia prevails, and in the second case illegal migration and terrorism are the concerns. The adoption of the EU's Global Strategy in 2016, which defines the vital interests of the EU, namely citizen security, prosperity, democracy, and global law-based order - represents a major breakthrough in defining the level of ambition and perception of the European security. Five priorities for external action have been identified based on the vital EU interests: a) the Security of our Union; b) State and Societal Resilience to our East and South; c) an Integrated Approach to Conflicts; d) Cooperative Regional Orders; e) Global Governance for the $21^{\text {st }}$ Century. ${ }^{29}$ Although the EUGS does

\footnotetext{
${ }^{27}$ Howorth, J. (2018), "Strategic autonomy and EU-NATO cooperation: threat or opportunity for transatlantic defence relations?", Journal of European Integration, 40(5), pp. 523-537, Available at: https://doi.org/ 10.1080/07036337.2018.1512268, (Accessed: 3 August 2020).

${ }^{28}$ Franke, U., Varma, T. (2019), "Independence play: Europe's pursuit of strategic autonomy”, European Council on Foreign Relations, Available at: https://www.ecfr.eu/specials/scorecard/independence_play_europes_pursuit_of_strategic_autonomy, (Accessed: 3 August 2020).

${ }^{29}$ EEAS (2016), op. cit.
} 
not contain detailed information on priorities, focusing on the security of the $\mathrm{EU}$ and its citizens and reducing the role of promoting democracy seem to be an important step that should have been taken much earlier. The content of the EUGS clearly indicates a lowering and thus a more realistic level of the European ambitions in the political sense, which is reflected by investments in the resilience of the States in the direct neighbourhood of the EU instead of a large transformational program for all. The content of the EUGS confirms NATO's key role in maintaining security in Europe, stating that, when it comes to collective defence, NATO remains the main structure in this area for most EU members.

\subsection{Harmonization of the development of defence capabilities}

Another question significantly affecting the EU's strategic autonomy includes issues of harmonization in developing desirable security and defence capabilities. Building new defence capabilities of the EU as well as improving and increasing the existing ones is one of the key elements ensuring the future strategic autonomy of the EU in the field of security and defence. Coordinated development of capability between the EU Member States is one of the priorities on the way to achieving strategic autonomy. Among the actions taken, particular attention should be paid to two initiatives: the Capability Development Plan (CDP) and Coordinated Annual Review on Defence (CARD).

The CDP will be an instrument linking other security and defence initiatives to ensure long-term coordination and integration of military capabilities in the EU. This results directly from the content of the EUGS, which speaks of strengthening the role of the CDP in the Member States' development of those capabilities that correspond with the EU's political goals in the field of security and defence. Current changes that are occurring in the area of the Community's security and defence policy mean that the CDP can become a signpost for the development of the EU defence capabilities, taking into account security threats, experience, lack of capabilities, political and industrial priorities, technological development, and the EU's global level of ambition. Consequently, the CDP is an important tool on the road to strategic EU autonomy in the field of security and defence. ${ }^{30}$

\footnotetext{
${ }^{30}$ Quain, C. (2019), "EU Strategic Autonomy: Filling the Gaps. A New Momentum for Common Security and Defence Policy", The Institute of International and European Affairs, Available at: https://docs.google. com/viewerng/viewer?url=https://www.iiea.com/wp-content/uploads/free-downloads-files/tempfiles/00213985000.pdf, (Accessed: 3 August 2020).
} 
CARD is a new instrument designed to give a picture of the current capabilities of the Member States and to regularly check the extent to which they are implementing the priorities of the EU's capability development plan. One of the obstacles limiting the Member States' cooperation in security and defence is the difference in defence planning cycles in NATO and the EU. The lack of coordination of defence planning within the EU has become a major factor in the decision to create a new initiative, which is a process to ensure access by the EU and its Member States to a systematic and comprehensive review of possessed, developed and planned military capabilities. In its assumptions, CARD is to assist the Member States in defence planning in the area of filling capability gaps related to the EU operations. The CARD mechanism is intended to support the Member States in obtaining critical capabilities based on the priorities contained in the CDP as well as to provide a forum for the exchange of information on the state modernization plans and possible coordination of activities. The European Defence Agency was identified as a key institution in the day-to-day management of the process. Under this mechanism, Member States will provide the EDA with information each year on defence spending, technical modernization plans, and involvement in research projects. Their analysis is to allow the development of recommendations regarding: implementation of the EU priorities in the field of developing military capabilities, the possibilities of deepening defence cooperation and achieving greater consistency in the defence planning of the EU Member States. ${ }^{31}$ The first trial review began in autumn 2017 and ended in summer 2018. The first full CARD is to be carried out in 2019-2020 and the conclusions from it are to be presented in an EDA report. The CARD process has the potential to change Europe's way of thinking about defence planning and capability building. This will require involvement of the Member States above on a simply declarative level. In turn, the EDA, as the secretariat of the entire mechanism, should focus on filling capability gaps, which will be a long-term process.

\subsection{Joint security and defence projects}

The third area relates to strengthening military cooperation between the EU Member States. Such cooperation has already been undertaken, even if it has been done as a part of the pooling \& sharing initiative, but in the future

\footnotetext{
${ }^{31}$ Mazurek, K. (2018), "European offensive in defense sphere - EDF, PESCO and CARD," Casimir Pulaski Foundation, Available at: https://pulaski.pl/wp-content/uploads/2018/11/European_offensive_in_defense_ sphere_EEDF_PESCO_and_CARD_PL.pdf, (Accessed: 3 August 2020).
} 
there would be Permanent Structured Cooperation (PESCO) that may prove to be a viable initiative providing the $\mathrm{EU}$ with access to specific military capabilities.

The PESCO mechanism was established by the Lisbon Treaty and has the potential to become one of the key elements of the new European security and defence architecture of the EU. ${ }^{32}$ Due to its authorisation in the Treaties, PESCO has an attribute of durability ensuring real cooperation between the Member States. The main advantage of PESCO, especially in relation to numerous previous declarations of states both within the EU and NATO, is its binding nature. In a situation where a state decides to participate in a given project under PESCO, it makes a binding commitment to fulfil it in the form of a so-called national implementation plan, the implementation of which will be monitored annually by the newly-created PESCO Secretariat supported by the EDA, the European External Action Service and the EU Military Staff, under the authority of the EU High Representative for Foreign Affairs and Security Policy. ${ }^{33}$ As the implementation of the project progresses, the countries will update their implementation plans, and at the end of each phase (i.e., in 2021 and 2025) a strategic review is foreseen regarding the progress of state commitments and the potential launch of the next phase or revision of the declaration.

In the area of improving command structures of joint missions, especially in relation to crisis management, the Military Planning and Conduct Capability (MPCC) unit was established, which aims to improve the functioning of the EU crisis management structures. The MPCC will function within the EU Military Staff as a part of the European External Action Service and will be in charge for coordination of ongoing training operations being conducted in Mali, Somalia, and the Central African Republic. Its main task will be the operational planning and conducting of military missions without an executive mandate, as well as the creation, mobilization, maintenance, and reconstruction of the EU forces. This approach will result in the concentration of mission staff on specific field operations supported by Brussels. ${ }^{34}$

\footnotetext{
${ }^{32}$ Biscop, S. (2018), “European Defence: Give PESCO a Chance”, Survival, 60(3), pp. 161-180, Available at: https://doi.org/10.1080/00396338.2018.1470771, (Accessed: 7 August 2020).

${ }^{33}$ Gotkowska, J. (2018), “The trouble with PESCO. The mirages of European defence", Centre for Eastern Studies, Available at: https://www.osw.waw.pl/sites/default/files/pw_69_pesco_ang_net.pdf, (Accessed: 7 August 2020).

${ }^{34}$ EEAS (2018, November), “The Military Planning and Conduct Capability (MPCC)”, Available at: https:// eeas.europa.eu/sites/eeas/files/mpcc_factsheet_november_2018.pdf, (Accessed: 7 August 2020).
} 


\subsection{Cooperation with a key partner - NATO}

A friendlier concept of NATO-EU relations was born out of necessity, because both organizations face new challenges in ensuring the security of the Member States..$^{35}$ On the eastern side, partners must engage in important undertakings to ensure the territorial integrity of NATO's eastern flank. From the west, the United States calls for renegotiation of burden shared within NATO. On the south side, constant problems have generated frequent crises that require intervention, partnership, and enormous reconstruction efforts, both economically and institutionally. In addition to the increased involvement of forces and competition in its neighbourhood, Europe must also formulate responses to its citizens' security concerns. ${ }^{36}$ The main areas include protection against terrorism, cyber-attacks, uncontrolled migration, and hybrid interference in democratic processes. Due to the fact that the former luxury of being able to deal with one problem in one place at a given moment has been consigned to history, it is clear that Europe's security requires joint efforts and resources of both the EU and NATO, which must cooperate with each other in order to meet multi-faceted internal and external challenges. ${ }^{37}$

In the coming years, even far-reaching EU reforms and initiatives under the CSDP will not be able to replace NATO; European leaders must be aware of the changing geopolitical priorities of the United States. This change is independent of the declarations or policies of recent US administrations and it is a part of a long-term trend. Although the United States will maintain military involvement in Europe, it will try to increase the burden on its European allies. The reduction of their commitment to the European security will not take place in the form of a sudden and radical change in policy, but as a part of a gradual change in Alliance agreements and US commitments. For these reasons, the EU members should not accelerate the process of US withdrawal, but they should prepare for it. In terms of security and defence, this means focusing on developing actual military capabilities, which takes much more time than developing agreements at institutional level.

Presented initiatives are aimed at strengthening the EU capabilities in the

\footnotetext{
${ }^{35}$ Howorth, J. (2017), "EU-NATO cooperation: the key to Europe's security future", European Security, 26(3), pp. 454-459, Available at: https://doi.org/10.1080/09662839.2017.1352584, (Accessed: 7 August 2020).

${ }^{36}$ Biscop, S. (2019), "Fighting For Europe. European Strategic Autonomy and the Use of Force", Egmont - Royal Institute for International Relations, Available at: http://www.egmontinstitute.be/content/uploads/2019/01/ EP103.pdf?type=pdf, (Accessed: 7 August 2020).

${ }^{37}$ Brustlein, C., (ed.), (2019), "Mutual Reinforcement. CDSP and NATO in the Face of Rising Challenges", Ifri, Available at: https://www.ifri.org/sites/default/files/atoms/files/fs93_brustlein_ed_mutual_reinforcement_2019.pdf, (Accessed: 11 August 2020).
} 
area of security and defence in order to achieve strategic autonomy. The general goal of strategic autonomy in security and defence and its accompanying instruments in the EU is finally to rearrange, harmonize and pool as well as share the European capabilities to prevent duplication. Pooling and sharing means not only cooperation but rather integration. As an alternative of simply collaborating in the field of security and defence, Europeans are establishing one body, one pool of capacities accessible to all of them. It is expected that the predominant result would be boosted effectiveness of the European defence so that Europe could reach the same level of cost-efficiency as its crucial partners, such as the U.S. Difficulties involving an integrated European defence structure still exist and cover different approaches concerning the EU-NATO relationship and the observation that defence integration may go against principle of national sovereignty. Nonetheless, the goal of strategic autonomy and being a prominent power on the world stage can only succeed if the EU's defence integration keeps moving forward.

\section{Conclusions}

The considerations set out above regarding the concept of the EU's strategic autonomy in the field of security and defence lead to the formulation of several conclusions. First, launching defence initiatives increases the EU's chances of achieving strategic autonomy in the field of security and defence in the future. An important role in this area will be played by the European Commission, which should supervise their implementation and development. Providing various sources of financing will increase the chances of implementing the developed defence projects, and thus achieving the objectives of strategic autonomy. The first effects are likely to be visible in the next few years (even up to a decade).

Secondly, the lack of consensus among the EU Member States regarding the understanding of the concept of strategic autonomy is not conducive to the consistency of the message regarding the level of its ambition, including its goals and priorities. The Member States and the EU institutions will continue to promote different concepts reflecting their own vision of defence cooperation. Such narrative may lead to a blurring of the idea of strategic autonomy. It is important that the concept of strategic autonomy will also depend on external factors. Re-election of Donald Trump as the President of the United States is likely to increase interest in strategic autonomy in the French image, and thus virtually complete independence. ${ }^{38}$ In turn, the victory of another candidate is

\footnotetext{
${ }^{38}$ Smith, M.E. (2018), "Transatlantic security relations since the European security strategy: what role for the EU in its pursuit of strategic autonomy?”, Journal of European Integration, 40(5), pp. 605-620, Available at: https://doi.org/10.1080/07036337.2018.1488840, (Accessed: 11 August 2020).
} 
likely to be conducive to the vision of strategic autonomy based on transatlantic ties, in particular in the field of security and defence. Thus, the nature of the transatlantic dialogue after the presidential election in the United States in 2020 will have a particular impact on the EU defence policy, including its industrial dimension. In turn, the development of security on the eastern and southern flanks will be determined by the perception of threats in Europe and may force the EU to make changes that will affect the perception of strategic autonomy. ${ }^{39}$ For the reasons mentioned above, the EU members should not create situations related to the possible withdrawal of the United States from the European defence, but at the same time they should prepare for it. ${ }^{40}$ In the field of the CSDP, this means focusing on development of actual military capabilities, which takes much more time than development of agreements at the institutional level.

Thirdly, stronger European defence capabilities and a more united European security policy are in the best interest of all EU members. The mere availability of a credible military force will improve the geopolitical position of the EU's negotiating position in the international arena, both in relation to great powers as well as small and weak adversaries. Europe's strengths in achieving strategic autonomy include its economic strength and the single market. In matters of regulation, trade, competition, and data protection, the EU is already seen as a strategic actor internationally. It provides a framework for defending and maintaining Europe's competitiveness for the EU Member States. In the field of security and defence, the CDP, CARD, PESCO and EDF initiatives have the chance to become the key in acquiring and developing the desired defence capabilities of the EU.

To sum up, the EU is on a long road to achieving strategic autonomy in the field of security and defence. It does not have to do this alone nor should it be expected to do so. The development of real defence capabilities must take place in with respect for the sovereignty of the Member States and with regard to the key partners, particularly including NATO. In this context, autonomy should mean the ability to act independently and include cooperation, and should not develop into isolation or, even more so, lead to divisions among the EU Member States.

August 2020

\footnotetext{
${ }^{39}$ Haugevik, K., Rieker, P. (2017), "Autonomy or integration? Small state responses to a changing European security landscape”, Global Affairs, 3(3), pp. 211-221, Available at: https://doi.org/10.1080/23340460.2017.1 377625, (Accessed: 11 August 2020).

${ }^{40}$ Fiott, D. (2018), “Strategic autonomy: towards 'European sovereignty' in defence?", European Union Institute for Security Studies (EUISS), Available at: https://www.iss.europa.eu/sites/default/files/EUISSFiles/ Brief\%2012_Strategic\%20Autonomy.pdf, (Accessed: 11 August 2020).
} 